\title{
Poverty Status and Dietary Diversity Among Farming Households in Gassol, Taraba State, Nigeria
}

\author{
Mailumo, S. S* Ajik, B. B. \\ Department Agricultural Extension and Management, Federal College of Forestry, \\ P. M. B. 2019, Jos, Plateau State, Nigeria
}

\begin{abstract}
This study examined the relationship between poverty status and dietary diversity among farming household in Gassol, Taraba State, Nigeria. Simple random sampling technique was employed to select 120 households in the study area from whom data were collected. The data were analyzed using Household Dietary Diversity Score (HDDS); Foster, Greer and Thorbecke (FGT) Index; and Tobit regression model. The result of HDDS showed that $92 \%$ of the farming households had low dietary diversity while the FGT result showed that $70 \%$ of the farming households were poor. Tobit regression revealed that the coefficients of household size, farm size, household dietary diversity and income from sales of non-agricultural goods were negatively significant; however gender and marital status were positively significant. Based on this, it was established that there is a significant relationship between poverty status and HDDS. This relationship was such that the higher the level of poverty, the lower the dietary diversity of the farming households. This implies that the poorer a farming household is, the lesser their dietary diversity and nutritional intake. This could be attributed to the minimal profit margin obtain by farmers owing to the fact that they mostly sell their farm produce immediately after harvest. Consequent upon this, they remain impoverished and unable to feed well. It is therefore recommended that the shelve lives of these agricultural produce should be enhanced through research. There is also need for the farmers to be educated on the importance of balance diet. Finally, they should be supported with nutritional supplements to improve their health status and consequently their poverty status.
\end{abstract}

Keywords: Poverty, dietary, diversity, farming, households, Gassol

DOI: $10.7176 / \mathrm{JESD} / 11-2-12$

Publication date: January $31^{\text {st }} 2020$

\section{Introduction}

Poverty has remained a global problem that continued to demean human dignity by making life to be degrading (Kwaghe et al., 2009). Poverty experience by Nigerians is pervasive, multifaceted and chronic, affecting the lives of a large proportion of the populace (Kwaghe et al., 2009). The issue of poverty has been a major concern to many nations, particularly the developing countries. Since independence in Nigeria, effort at national and community development has been aimed at reducing poverty and promoting growth. Poverty in Nigeria remains significant despite high economic growth reported in the country. It first started sometimes during the British Empire. Oshewolo (2010) reported that Nigeria is richly endowed and the country's wealth potential manifest in the form of natural, geographical and socioeconomic factors. With this condition, Nigeria rank among the richest countries of the world that should have no business with extreme poverty. Similarly, Nigeria's economic growth rate averaging $7.4 \%$ has been reported to be one of the world's highest (NBS, 2013). Inspite of this, the country has experienced a massive increase in the level of poverty reported to be $74.2 \%$ in the year (Oshewolo 2010). The National Bureau of Statistics presented a grim statistics of Nigeria's population in abject poverty. The report that about 112 million Nigerians actually lived below the poverty line (NBS, 2012). The population of Nigerians in poverty has increased considerably with about $67 \%$ of the entire population in 2013 (World Bank, 2013). Consequently, the menace of poverty in Nigeria is an incontrovertible fact which has a concomitant effect of hunger, ignorance, malnutrition, disease, unemployment, poor access to credit facilities and low life expectancy as well as a general level of human hopelessness.

Worldwide, around 925 million people are chronically hungry due to extreme poverty, while up to two billion people lack food security intermittently due to varying degrees of poverty (FAO, 2012). Household food insecurity is directly influence by a low access to food. Consequently households that lack access to food generally have low dietary diversity, indicating deficiency of basic nutrients. Dietary diversity is the number of different foods or food groups consumed by the household over a reference period not regarding frequency of consumption (Hoddinott and Yohannes 2002). It is an outcome measure of food security at the individual or household level. In the present study, dietary diversity refers to the number of food groups consumed over a 24 hours period.

Household dietary diversity is influence by accessibility to food. It is estimated that close to one billion people in the world suffer from hunger and food insecurity - define as not having enough calories to live a healthy life (Nmadu, et. al. 2014). Nearly the entire undernourished people are in developing countries with worst scenarios in Asia (578 million) and sub-Saharan Africa (239 million) (IFPRI, 2011). In the case of Nigeria, an estimated 61 percent of the people are malnourished (Momodu, et al, 2011). 
The number of people in Nigeria who lack access to nutritious foods rich in essential micronutrients such as fruit and vegetable, meat, fish, dairy products and biofortyfied staple foods is staggering (FAO, 2011). This lead to deficiency in micronutrient such as vitamin A, iron and Zinc and affect the survival, health, development and well-being of billions of people. However, it has been observed that the more food groups included in a daily diet the greater the likelihood of meeting nutrient requirement while monotonous diets, base mainly on starches such as maize and bread have been closely associated with food insecurity and poverty. This study therefore analyzed the relationship between poverty and dietary diversity among households in Gassol Local Government Area, Taraba State.

\section{Theoretical underpinning}

A search of relevant literature shows that there is no generally accepted definition of poverty. This is because poverty more often than not affects the entirety of human condition including moral, psychological and physical. This makes a concise and universally accepted definition of poverty to be elusive. Little wonder Udusola (1997) reported that poverty like an elephant, is easier to recognize than to define. In simple language, poverty, like beauty, lies in the eye of the beholder (Townsend, 1979, Kwaghe, 2006).

This study recognized the definition of poverty in both absolute and relative terms as observed by Omeiza (2009) where poverty is understood to be a multifaceted concept which manifest itself in different forms depending on the nature and extent of human deprivation. In absolute terms, poverty refers to insufficient or in rare cases, the total lack of basic amenities like food, housing, medic care, education, consumer goods and opportunities. In relative terms, humans are poverty stricken when their homes fall radically below the community average (Omeiza, 2009). This suggest that such a people cannot have what the larger society regards as the minimum necessity for a decent living. A simplified view of the poor is that which is expressed by a poor man in Kenya in 1997 as reported by Narayan, et. al. (2000) thus: "Don't ask me what poverty is because you have met it inside my house. Look at the house and count the number of holes. Look at my utensils and the clothes that I am wearing. Look at everything and write what you see. What you see is poverty". In line with these definitions therefore, poverty refers to inadequate basic necessities for human survival.

The theoretical base of various researchers were located in the Human Capital Theory made popular by (Amacher, 1986; Scultz, 1960 and 1961; and Tilak, 2002). Human Capital Theory is a welfare economic theory that holds that investments in health, education and skills of citizens is more productive than investment in machines, bridges and tractors. Scultz (1975) asserted that human capital theory not only account for the shape of income distribution, but also the unexplained variation in earnings among individuals, regions and subgroups in the society. Amacher (1986); Tilak (1994 and 2005) opined that most low income countries invest very little in Human Capital or the health, education and skills of their citizens. They argued that increase in human capital reduces the level of poverty.

Quite a number of economic researchers (James, 2006 and Lynne, 2002) established that there is a positive link between educational attainment and the economic status of individuals in relation to their regions or countries of abode. This mean that people with higher levels of education earn substantially more than those with less. In general, citizens of developed countries with higher proportions of better educated citizens achieved higher standards of living than countries with lower proportions.

The basic physical need approach views poverty in very broad term such as being unable to meet basic physical needs (food, water, clothing and shelter) requirements of a "meaningful life" (Streeten, 1979 and 2000 ; Blackwood and Lynch, 1994 and Oluwa, 2012). This idea of poverty as propounded by the above scholars attracted tremendous criticisms. Elements of these basic human needs include food, water, clothing and shelter. Incidentally, these are also the elements of the lowest level of Maslow's hierarchy of needs (Hagarty, 1999). These needs according to Maslow must be satisfied in order to survive and if there is an acute deficiency, he argued the individual will react by directing most of his/her energies towards obtaining the minimum requirement for physical survival. In the event of a failure to secure this minimum, Maslow maintained that it will lead to impaired physical efficiency and eventual death. In the light of this, the World Bank report (1991) based its notion of absolute poverty and it forms the basis for the specification of poverty line.

Adeyeye (2000) observed that this idea of poverty is limiting, in the sense that it cannot form the basis for interpersonal, inter temporal, international and even spatial comparisons. Despite the criticisms, the notion of absolute poverty however remains relevant, especially in areas prone to famine and other natural and man-made disasters. The concept of absolute poverty is also relevant in that it is the type of poverty that policy makers and international development agencies are striving to eliminate. There is uniformity from the foregoing definitions of poverty above. In each case, emphases were laid on basic needs, physical or non-physical needs or even all in some cases.

Information about the individual or household dietary diversity in populations can serve as a simple indicator of food security and poverty status (Azadbakht et al, 2006). Food security entails three important aspects (availability, access and utilization) in the relationship between man and food, necessary to ensure that nutrition 
plays its optimum role in human health. Dietary diversity has been positively linked with these three pillars of food security (Hoddinnott and Yohannes, 2002). Individual and household access to food has also been shown to be affected by demographic and socioeconomic factors, accounting for variations in diet quality (Kwaghe, 2006). Studies have demonstrated the contribution of dietary diversity to population-level nutrient adequacy in developing countries, with fewer studies considering the value of cultivated and wild biodiversity (Ruel, 2003). It has recently been shown that in a peri-urban area of Dakar, Senegal (in west Africa), dietary diversity is positively correlated with intakes of several key nutrients, specifically $\mathrm{Ca}, \mathrm{Fe}, \mathrm{Zn}$, vitamin $\mathrm{A}$, vitamin $\mathrm{C}$, thiamin, riboflavin and vitamin B6 (Kennedy, et. al. 2009). The study in Vietnam, which included adult women, validated the diversity measures against nutrient intake and nutrient density. The findings confirm a positive association between the two measures of diversity and intake of energy and a variety of nutrients. Using a multi -country analysis of data from 10 countries Hoddinott and Yohannes (2002) tested whether household dietary diversity was associated with consumption/expenditure and food security. The results indicate that as income increases people tend to diversify their diet (Torheim et al., 2004). Diversity also significantly improves dietary quality and the likelihood that individuals will meet their daily nutrient requirements, especially with regard to essential micronutrients and it may be a good proxy for greater income/expenditure and food security (Heady and Oliver, 2013).

This paper follows the conventional view of poverty as a result of insufficient income for securing basic foods with the resultant effects as malnutrition, sickness and diseases. The emphasis here is with the individual's ability to subsist and to procreate as well as to command resources to achieve a living (Sen, 2004 and 2005; Amins and Rakodi, 1994). Historically this involves a transition from a situation where subsistence depends upon wages with which to purchase foods.

\section{Methodology}

3.1Study Area

Gassol is a Local Government Area in Taraba state, Nigeria. It's headquarter is in the town of Mutum Biyu on the A4 highway. It is located between latitude $8^{\circ} 24^{\prime}$ and $8^{\circ} 40^{\prime} \mathrm{N}$ and longitudes $10^{\circ} 32^{\prime}$ and $10^{\circ} 53^{\prime} \mathrm{E}$. It has an area of about $5,548 \mathrm{~km}^{2}$. Based on a population growth rate of 3 percent, the estimated projected population stands at 328,922 (2006 census projected to 2016). The northern border of Gassol is the Benue River, the Taraba River flows north through the area and empties into the Benue. Gassol is one of the eight LGA's of Taraba state whose majority population is the mumuye people. The major crops grown are: Yam, cassava, maize, guinea corn, cowpea, egusi and groundnut.

\subsection{Sampling Technique and Procedure.}

Farming household constituted the population of this study. There are twelve (12) major villages in the study area (Mutum Biyu A, Mutum Biyu B, Sabongida, Sendirde, Shira, Namnai, Yerima, Tutare, Gassol, Wuryo, Gunduma and Wurojam). Six (6) villages were randomly selected using balloting techniques. In each village a proportionate number $(10 \%)$ of respondents were selected from the sample frame. Questionnaires were administered to households in the ratio as follows: total of 25 questionnaires were administered in Gassol, 25 in Mutum Biyu A, 20 in Gunduma, 20 in Shira, 15 in Yerima, and 15 in Tutare making the total of one hundred and twenty (120) questionnaires. The distribution was informed by the number of active farming households in the villages.

\subsection{Data Analysis.}

Primary data was used for this study. Primary data was sourced from a set of well-structured research questionnaire in line with the stated objectives of this work which was administered to the selected households in the study area. Data generated was analyzed using Household Dietary Diversity Score (HDDS); Foster, Greer and Thorbecke (FGT) Index, and Tobit Regression.

\subsubsection{Household Dietary Diversity Score (HDDS)}

Data on household dietary diversity was collected using 24 hour dietary intake. The information collected on dietary consumption was used to calculate a dietary diversity score (DDS), define as the number of different food groups consumed by family members over 24 hours. Dietary data was collected by means of a validated 24 hours recall which is not quantified. Respondents were visited in their homes during the survey. Both spouses constituted the respondents. The women were involved because they are mostly in charge of cooking meals for households, it is assumed that they have good ability to remember foods eaten (Haggblade, et .al., 2007). For this study the twelve (12) food groups recommended by Food and Agriculture Organization of the UN (FAO, 2007) was used to assess household dietary diversity scores (DDS).The 12 food groups are:
1. Cereal.
7. Fish and other sea food.
2. White roots and tubers.
8. Pulses, Legumes and Nuts.
3. Vegetables.
4. Fruits.
9. Milk and Milk products.
10. Oils and Fat. 

5. Meat.
11. Sugar / honey
6. Eggs.
12. Spices, Condiments and beverage.

3.3.2 Foster Greer Thorbecke (FGT) Index.

FGT was used to assess the poverty status of the respondents. The FGT consider poverty as dependent on the poverty gap ratio, and assume as the power of that ratio, thus;

$$
p a=\frac{1}{n} \sum_{1=1}^{q}\left[z-\frac{y}{y}\right]=\frac{q}{n} \sum_{1=1}^{0}\left[z-\frac{y}{y}\right] q
$$

Incidence of poverty $=\frac{q}{n}$

Where:

$\mathrm{Yi}=$ the average consumption per capita for the $1^{\text {st }}$ household When household are ranked in ascending order of consumption.

$\mathrm{Z}=$ the poverty line.

$\left[\mathrm{Z}-\mathrm{Y}_{\mathrm{i}}\right]=$ the poverty gap household 1 .

$\mathrm{n}=$ the total number of the household below poverty line.

$\mathrm{q}=$ the FGT and it takes values as $0,1,2$.

3.3.3 The Tobit Regression

The Tobit model is expressed following Tobin (1958). Tobit decomposition framework examined the relationship between poverty status and the socio - economic factors that influenced poverty among the respondents. The Tobit Model can be mathematically expressed as:

$$
\begin{aligned}
& \mathrm{V}_{\mathrm{i}}=\mathrm{V}_{1}=\beta \mathrm{X}_{\mathrm{i}}+\varepsilon_{\mathrm{i}} \text { if } \mathrm{V}_{1}>\mathrm{V}_{1} \text { * } \\
& \mathrm{V}_{0}=\beta \mathrm{X}_{\mathrm{i}}+\varepsilon_{\mathrm{i}} \text { if } \mathrm{V}_{1} \leq \mathrm{V}_{1}^{*}
\end{aligned}
$$

Where:

$\mathrm{V}_{\mathrm{i}} \quad=$ the dependent variable, it is discrete when the households are not poor and continuous when they are poor.

$\mathrm{i} \quad=1,2, \ldots, \mathrm{N}_{\mathrm{i}}$, where $\mathrm{N}_{\mathrm{i}}$ is the total number of poor households.

$\mathrm{V}_{1} \quad=$ Limited dependent variable, it is the poverty depth/intensity defined as $\left(\mathrm{Z}-\mathrm{Y}_{\mathrm{i}}\right) / \mathrm{Z}$, where $\mathrm{Z}$ is the poverty line and $\mathrm{Y}_{\mathrm{i}}$ is MPAEHE

$\mathrm{V}_{1} * \quad=$ the poverty depth when the poverty line $(\mathrm{Z})$ equals the MPAEHE (here $\mathrm{V}_{1} *=0$ )

$\mathrm{X}_{\mathrm{i}} \quad=$ vector of explanatory variables

$\beta \quad=$ vector of unknown parameters

$\varepsilon_{\mathrm{i}} \quad=$ independently distributed error term.

The empirical model used for determining socio economic factors that influenced poverty among farming households in the study area was specified as:

$V_{1}=\beta_{0}+\beta_{1} X_{1}+\beta_{2} X_{2}+\beta_{3} X_{3}+\beta_{4} X_{4}+\beta_{5} X_{5}+\beta_{6} X_{6}+\beta_{7} X_{7}+\beta_{8} X_{8}+\beta_{9} X_{9}+\beta_{10} X_{10}+\beta_{11} X_{11}+\beta_{12} X_{12}+\varepsilon_{i}$

Where:

$\mathrm{V}_{1}=$ limited dependent variable, it is the poverty depth/intensity

$\beta_{0}=$ constant (autonomous poverty depth)

$\beta_{\mathrm{i}} \quad=\quad$ vector of unknown parameters

$\varepsilon_{\mathrm{i}} \quad=\quad$ independently distributed error term

$\mathrm{X}_{1}=\quad$ Age of the respondent (years).

$\mathrm{X}_{2}=$ Gender.

$\mathrm{X}_{3}=$ marital status.

$\mathrm{X}_{4} \quad=\quad$ Educational level (years).

$\mathrm{X}_{5}=$ Household size (numbers).

$\mathrm{X}_{6}=$ Farming experience (years).

$\mathrm{X}_{7}=$ Farming size (ha).

$\mathrm{X}_{8}=$ Part time occupation.

$\mathrm{X}_{9} \quad=\quad$ Distance to nearest market $(\mathrm{km})$.

$\mathrm{X}_{10}=$ Dietary diversity $(1=$ high DDS, $0=$ low DDS $)$

$\mathrm{X}_{11}=$ Income from agricultural products $(\#) \backslash$

$\mathrm{X}_{12}=$ Income from non-agricultural product $(\AA)$

\section{Result and Discussion}

\subsection{Food Intake Diversity}

Twelve (12) food groups included in the (Household Dietary Diversity Score) were cereals, roots and tubers, legumes and products, meat and product; fish and sea foods; dairy and products, fruits and product, bakery product; fat and oils, poultry and eggs and miscellaneous. These food groups were used to identify food intake quality of households in the study area. Dietary diversity indexes have been shown to be good proxy for calorie intake and nutritional outcomes (Ruel, 2006). The frequency distribution of household dietary diversity index presented in 
Table 1 shows that $92 \%$ of the sampled household had 0-6 food groups in their diet per day, while $8 \%$ of the households had 7-12 food groups in their diet. This implies that most households had low food intake diversity per day due to competing demand on available household income which limits their access to varieties of foods. Also, this result was not unexpected because some of the households do not produce significant share of their own food. Hence they were more exposed to rising food prices which influences their level of food diversity. Household access to food was therefore an important variable in food diversity level in the study area.

Table: 1 Dietary Diversity of Households

\begin{tabular}{lcc}
\hline Dietary Diversity & Frequency & Percentage \\
\hline $0-6$ & 110 & 91.7 \\
$7-12$ & 10 & 8.3 \\
Total & 120 & 100 \\
\hline
\end{tabular}

Source: Field survey 2018

\subsection{Poverty profile}

The respondents were classified into an exclusive group separated by the line either as poor or non - poor . The poverty line use for this study was calculated from the yearly household expenditure (THE) of sample household. Two third $(\$ 52,812)$ of the yearly THE of the sample households was use as the poverty line. The poverty status category of households included: Poverty head count or incidence $\left(P_{0}\right)$, poverty gap or depth $\left(P_{1}\right)$ and squared poverty gap or security $\left(P_{2}\right)$.

The $P_{0}$ for the household was 0.7 . This means that $70 \%$ of the farming households in the study area were poor. The poverty gap index $P_{1}$ was 0.415 , this implies that $41.5 \%(\$ 21,916.98)$ of the poverty line was required to bring an average poor individual in the study area to the poverty line. The Poverty index which measures the distance of each poor person to one another was found to be $0.219, P_{2}$ showing that $21.9 \%$ of the poor households were severely poor. This indicated inequality in the degree of poverty among poor households.

Table 2: Poverty profile of Households

\begin{tabular}{lrr}
\hline Poverty profile & Frequency & Percentage \\
\hline Non Poor & 36 & 30 \\
Poor & 84 & 70 \\
Total & 120 & 100 \\
FGT Food Index & & \\
Poverty incidence $\left(P_{0}\right)$ & & 0.7 \\
Poverty Depth $\left(P_{1}\right)$ & 0.415 & \\
Poverty Severity $\left(P_{2}\right)$ & & 0.291 \\
\hline Poverty Line & & \\
THE & & \\
$2 / 3 *$ THE & N79218 per annum & \\
\hline
\end{tabular}

Note: THE mean Total Households Expenditure

\subsection{Relationship between Poverty Status and Household Dietary Diversity.}

The Tobit regression model was used to determine the relationship between poverty status and the socio economic factors that influenced poverty among the respondents in the study area. It measured the parameters of the conditional probability of being poor and the marginal changes in explanatory variables on the poverty status of the respondents. Respondents were classified into poor and non-poor using the poverty line as derived from The Household Expenditure (THE). The regression parameters and diagnostic statistics were estimated using the maximum likelihood estimation (MLE) technique.

Results showed that only six out of the twelve listed regressors had significant influence on the poverty status of the farmers. The Log likelihood function is negative (-52.673) while the Chi- square value is positive and significant. This implies that there is a relationship between poverty status and dietary diversity in the study area. The variables that had significant co-efficients are gender, marital status, household size, farm size, HDDS and income from non-agricultural products. It should be noted that a positive sign on a parameter indicated that higher values of the variable tend to increase the likelihood of being poor. Similarly, a negative value of a co-efficient implied that higher values of the variable would decrease the probability of being poor; all things being poor.

The co-efficient of gender of the household head is 0.339 . This implies that relative to the female-headed households, the level of poverty will be reduced by 0.339 for male-headed households, hence having a poverty depth of 0.076 as against 0.415 for female-headed households. This could be attributed to the involvement of maleheaded household in different forms of off-farm activities. The co-efficient of marital status of household head is 0.099 , implying that the poverty status of household headed by married people will be increased by $9.9 \%$ to become $51.4 \%$, while that of households headed by un-married people will remain as $41.5 \%$. The reason for this is married 
households tend to have larger household size, which raises the dependency ratio.

Household size was found to have a negative coefficient and significant at $10 \%$ level. This means that the larger the household the lower the poverty status, an increase in the household size will probably lead to a reduction in poverty status of the households. Farm size of the households was found to have a negative coefficient and significant at $10 \%$ level. This means that farm size is inversely proportional to poverty status that is, an increase in farm size will probably lead to a reduction in poverty status of the households. Non-agricultural income was also found to have negative coefficient and significant at $10 \%$ level. The availability of additional income beside agriculture will reduce poverty status of the households. That is, an increase in non- agricultural income will probably lead to a reduction in poverty status.

The Dietary Diversity Score of farming household, had a negative coefficient and significant at $5 \%$ level, meaning that an increased in the varieties of foods consumed by households, could lead to a reduction in poverty. Thus, the poorer the farming household is, the lower their dietary diversity score. The effect of dietary diversity on the household might result in low productivity and therefore poverty. This is because the lower the dietary diversity of a farming household the lower their nutritional intake and this might subsequently affect health of the household members which will reduce farming productivity, and thus increase the poverty status of that household (Hoddinott et, al. 2006).

Table 3: Tobit Regression showing the relationship between poverty status and dietary diversity among farmers in Gassol

\begin{tabular}{lrrr}
\hline Variable & Coefficient & Std error & T-value \\
\hline Constant & -0.310 & 0.262 & -1.183 \\
Age & 0.009 & 0.026 & 0.347 \\
Gender & 0.339 & 0.149 & $2.274^{* *}$ \\
Marital Status & 0.990 & 0.568 & $1.743^{*}$ \\
Education & -0.036 & 0.046 & -0.783 \\
Household size & -0.262 & 0.148 & $-1.771^{*}$ \\
Years of farming & 0.019 & 0.034 & 0.559 \\
Farm Size & -0.206 & 0.119 & $-1.73^{*}$ \\
Occupation & -0.111 & 0.665 & -0.167 \\
Market Distance & 0.142 & 0.103 & 1.379 \\
Dietary diversity score & -2.276 & 1.01 & $-2.254^{* *}$ \\
Agricultural products income & $-4.09 \mathrm{E}-07$ & $1.14 \mathrm{E}-06$ & -0.359 \\
Non-Agric products income & $-4.09 \mathrm{E}-06$ & $2.21 \mathrm{E}-06$ & $-1.851^{*}$ \\
Log likelihood function & -52.673 & & \\
Prob> chi2 & 0 & & \\
Pseudo R2 & 0.28 & & \\
\hline Source: Analysis of data from Fid & & & \\
\hline
\end{tabular}

Source: Analysis of data from Field Survey, 2017

Note: $*$ and $* *$ means significant at $10 \%$ and $5 \%$ levels of probability.

\section{Conclusion}

Studies have shown a direct relationship between food insecurity, hunger and poverty. One of the contributing factors to food insecurity is socio-economic status. Limited income causes people to restrict the number and quality of meals they eat, reduce dietary variety, and look for inexpensively processed food. These options are usually low in essential nutrients and high in fats with empty calories.

It is reported that Nigeria's total agricultural output in areas of food production (including livestock and fishing), processing and marketing accounted for about $80 \%$ by value. However, in spite of the increase of food to the Nigerian agricultural economy, the food intake in the country is still inadequate in terms of quantity and quality. Food consumption studies assess immediate causes of malnutrition, and food security studies predict the adequacy of household dietary intake and nutritional status. Widespread poverty resulting in chronic and persistent hunger is the biggest problem in the developing countries. In Nigeria, malnutrition is associated to food shortage linked to both quantity and quality of food to provide a balance diet.

The frequency distribution of household dietary diversity index presented in this study shows that $92 \%$ of the sampled household had 0-6 food groups in their diet per day, while 8\% of the households had 7-12 food groups in their diet. This implies that most households had low food intake diversity per day due to competing demand on available household income which limits their access to varieties of foods. The study found that there is significant relationship between poverty status and dietary diversity. This relationship was found to show that the higher the level of poverty, the lower the dietary diversity of the farming households. Thus, the poorer the farming household is, the lesser their dietary and nutritional intake. To ameliorate poverty and inadvertently improve their dietary and nutritional intake, it is recommended that:

a. The capacity of farming households be built to take farming as a business through sensible 
management of resources.

b. Simple ways of adding value to their produce with a view of enhancing their shelve lives should be developed through research. They should also be enlightened on the importance of good and balanced nutrition.

c. Both the government and non-governmental organizations should make it a task to provide these rural farmers with nutritional supplements to improve the nutritional intake and consequently make them healthy.

\section{REFERENCES}

Adeyeye, V. A. (2000). Designing and Managing Poverty Alleviation Programme in Nigeria: The Micro Project Option. Paper presented at the workshop on Poverty Alleviation Policies and Strategies, organized by National Centre for Economic Management and Administration (NCEMA), Ibadan, Nigeria.

Amacher, R. C. (1986). Principles of Macro Economics, Ohio: Western Publishing

Azadbakht L. and Esmaillzadeh, A. (2010). Dietary diversity Score is related to 'Obesity And abdominal adiposity among Aranian Female Youth. Public Health Nutrition 14:62-69.Bioversity International, Rome).

Food and Agriculture Organization (2006). The state of food insecurity in the world: Monitoring progress towards the world food summit and Millenuim Development Goals. Rome F.A.O.

Food and Agriculture Organization (2011). Food Insecurity in the World: Addressing Food Insecurity in Protracted Crisis. Food and Agriculture Organization of the United Nations, Rome. Online available at:hhtt://www.fao.org/docrep/013/;1683e.pdf accessed on 25/02/2012

Food and Agriculture Organization (2012). Gender inequalities in Rural Employment in Ghana an overview. Prepared by the Gender, Equity and Rural Employment Division FAO, Rome, Italy. Food policy Research institute, Washington; 2012.

Hagarty, M. R. (1999). Testing Maslow's Hierarchy of Needs: National Quality of Life across Time. Sicial Indicator's Research 46, 249 - 271

Haggblade, S.; Hazell, P. B. and Reardon, T, (2007) (eds). Transforming the Rural Nonfarm Economy: Opportunities and Threats in the Developing World (Johns Hopkins Univ Press, Baltimore

Hoddinnott, J. and Yohannes, Y. (2002). Dietary Diversity as a Food Security Indicator. FANTA 2002, Washington D.C Retrieved from http://www.aed. Org / Health /Upload/ dietary Diversity. pdf.

IFPRI (2011). Global Nutrition Report (2014) Actions and Accountability to Accelerate the World's P rogress on Nutrition (International Food Policy Research Institute, Washington, DC).Insecurity in Protracted Crisis. Food and Agriculture Organization of the United Nations, Rome. Online available at: hhtt://www.fao.org/docrep/013/;1683e.pdf accessed on 25/02/2012.

James, J. H. (2006). Catch 'em Young. The Wall Street Journal (10)

Headey, D. and Olivier, E. (2013). Rethinking the Measurement of Food Security: From First Principles to Best Practice. Food Security 5 (3): 327-43. Health Population on Nutrition 19(3):167-176

Kennedy G., Fanon-Fogny, N.; Seghleri, C.; Arimond, M. and Koresi Y. (2009). Evaluation of dietary diversity Score for assessment of micro nutrient intake and food security in developing countries. 2009.

Kwaghe, P. V; Amaza, P. S; and Jafaru-furo, M. R. (2009). The relationship between Soleal factors and poverty Exposure by Farming Household in Taraba State, Nigeria. Global AgricSci 8(2):119-126 Lancet 382 (9890). 375 - 375. Library of science medicine 360: $134-1360$.

Kwaghe, P. V. (2006). Poverty Profile and its Determinants among Farming Households in Borno State, Nigeria. PhD Thesis, Department of Agricultural Economics, University of Maiduguri, 99-105pp

Lynne, K. (2002). Investing in the Future: Reducing Poverty through Human Capital Investments in understanding Poverty, Harvard University Press

Momodu, A. S., Akinbani, C. A. and Obisanya, J. F. (2011) Achieving food security and climate

Monitoring progress toward the world food summit and Millenuim Development Goals.

Narayan, D., Chambers, R., Shah, M. K. and Petesch, P. (2000). Voices of the Poor: Can Anyone Hear Us? New York: Oxford University Press

National Bureau of Statistic (2013). Gross domestic products for Nigeria. Document Necessary in developing countries. Nigeria .J. sustain. Dev AFr 12;6. Nigeria Gender perspective. Africa, Environ. Sci. Tech.2011.

Nmadu J, N., Gajere, R. A., Odine, A. I. and Sallwan, H. (2014). Dynamic of Poverty and Food Nutrition 13: 5660. Of diets. Tehram lipid and Glucose study. Asia Pacific Journal of clinical of the preliminary guidelines among women in kwazulu - Nantal and the Online available at: hhtt://www.fao.org/docrep/013/;1683e.pdf

Oluwa, O. W. (2012). Concept, Measurement and Causes of Poverty: Nigerian perspective. American Journal of Economics 2(1): 25-36

Omeiza, O.U. (2009). An Empirical Evaluation of the Poverty Alleviation Strategies in Nigeria. Sahel Analyst. Journal of the Faculty of Social Sciences 11(1), 88-96pp

Oshewolo S. (2010).”Galloping poverty in Nigeria: an Approval Government Pingali, P. (2015). Agricultural 
Policy and nutrition outcome-getting beyond the Preoccupation with staple grain. Food security 7(3).583-591.

Ruel, M. (2006). "Is Dietary Diversity an Indicator of Food Security or Dietary Quality? A Review of Rural Bangladesh, increasing the risk of malnutrition due to the financial crisis.

Scultz, T. W. (1960). Capital Formation by Education. Journal of Political Economy, 68(6).

Scultz, T. W. (1961). Investment in Human Capital, American Economic Review, 51

Scultz, T. W. (1975). The value of the ability to deal with disequilibria. Journal of Economic Literature, 13

Sen, A. (2004). How Does Culture Matter? In Rao, Vijayendra, Walton, Michael. Culture and Public Action, Stanford, CA: Stanford University Press, 37-58

Sen, A. (2005). Human Rights and Capabilities. Journal of Human Development 6(2): 151-166pp.

Streeten, P. (2000). Freedom and Welfare: A Review Essay on Amartya Sen, Development as Freedom. Population and Development Review 26(1): 153-162

Streeten, P. (1979). Basic Needs: Premises and Promises. Journal of Policy Modelling

Torheim .L.E.F., Diarra M.M., Thiam, F.D, Barikmo, I. and Hatloy, A. (2004). Food Insecurity and Vulnerability Information and mapping system. www. FVIMS. Org.

Tilak, J. B. G. (1994). Education for Development in Asia. New Delhi: Sage Publications.

Tilak, J. B. G. (2002). Education and Poverty. Journal of Human Development 3(2).

Tilak J. B. G. (2005). Post Elementary Education, Poverty and Development in India. Working paper series - N6 (REVISED). Center for African Studies, University of Edinburg.

Tobin, J (1958). Estimation of Relationships for Limited Dependent Variables. Econometrica. 12 (7): $26-32$

Townsend, P. (1979). Poverty in the United Kingdom: A Survey of Household Resources and Standard of Living. Penguin Books, 32-60

World Bank (2001). World Development Report. World Bank, Washington DC, USA

\section{Abridge Biography of First Author}

My name is Sunday Mailumo Sambo (PhD). I was born in Bassa Local Government Area of Plateau State, Nigeria, on $15^{\text {th }}$ December, 1974. I joined the Forestry Research Institute of Nigeria in 2002 and posted to the Federal College of Forestry, Jos, as an Assistant Lecturer where I rose through the ranks to a Principal Lecturer. I have a Ph.D in Agricultural Economics from the Ahmadu Bello University, Zaria. I equally had my first and second degrees in the same field from Abubakar Tafawa Balewa University Bauchi, Nigeria. My main areas of research interest spans through Production, Environmental and Welfare Economics with a bias in gender and livelihoods. I have published a text, 25 journal articles (in both international and national journals) and presented almost 30 conference papers where I made useful recommendations. I am presently a member of the Nigerian Association of Agricultural Economists (NAAE), Farm Management Association of Nigeria (FAMAN) and Forestry Association of Nigeria (FAN). I have worked in teams that consulted for some international agencies on production, livelihoods, impact evaluation and adoption of agricultural policies among others. 